\title{
Drone as a tool for coastal flood monitoring in the Volta Delta, Ghana
}

\author{
Kwasi Appeaning Addo ${ }^{1^{*}}$, Philip-Neri Jayson-Quashigah', Samuel Nii Ardey Codjoe ${ }^{2}$ and Francisca Martey ${ }^{3}$
}

\begin{abstract}
Background: Monitoring coastal erosion and flooding in deltaic environment is a major challenge. The uncertainties associated with land based methods and remote sensing approaches affect the levels of accuracy, reliability and usability of the output maps generated. This study monitored flooding and erosion activities in a flood prone fishing community (Fuvemeh) in the Volta Delta in Ghana using Unmanned Aerial Vehicles (UAVs) or drone technology.

Results: The study revealed that coastal flooding and coastal erosion have destroyed sources of livelihood and increased risk to life and property in the Volta Delta communities. It was identified that between 2005 and 2017 the shoreline has moved several meters inland (over $100 \mathrm{~m}$ along some transects) in some areas, while in other areas about 24,057 $\mathrm{m}^{2}$ land has been gained (about $80 \mathrm{~m}$ along some transects) that can serve as natural fish landing site. It emerged that over 77 houses have been destroyed which resulted in the displacement of over 300 inhabitants between 2005 and 2017. The study estimated that about 37\% of the total land area in Fuvemeh has been lost as a result of erosion.

Conclusion: Coastal erosion and flooding are major environmental challenges in the Volta delta. Coastal erosion has destroyed natural fish landing sites, which has affected the local fishing business (the main source of livelihood) and increased poverty. Coastal flooding has displaced inhabitants from their homes and increased migration from the Fuvemeh community.
\end{abstract}

Keywords: Volta Delta, Flooding, Drone, Unmanned aerial vehicle (UAV), Coastal Erosion, Coastal monitoring

\section{Background}

Delta environment is dynamic, highly vulnerable and challenged due to adverse impacts of flooding probably as a result of relative sea level rise, extreme oceanic wave actions, and subsidence or anthropogenic impact such as dam construction etc. (Ericson et al. 2006; Wong et al. 2014; Appeaning Addo 2015). Variety of methods that differ in approach, accuracy, cost and duration have been developed to meet the demand for higher accuracy in delta environment monitoring (Appeaning Addo et al. 2008). These methods can broadly be categorized as in-situ (physical surveying) method and remote sensing approach.

The physical surveying method has resulted in the production of historical maps at varying scales, which can be combined with recent information on the delta

\footnotetext{
* Correspondence: kappeaningaddo@ug.edu.gh

${ }^{1}$ Department of Marine and Fisheries Sciences, College of Basic and Applied

Sciences, University of Ghana, P. O. Box Lg 99, Legon, Accra, Ghana

Full list of author information is available at the end of the article
}

environment to detect and measure change in the shoreline morphology (Appeaning Addo et al. 2008). The remote sensing approach includes aerial photographs, satellite imagery, airborne light detection and ranging technology (LIDAR), and video technique.

The land based methods and the remote sensing approaches have their strengths and weaknesses, which can affect their levels of accuracy, the reliability of the output maps generated and their usability. These strengths and weaknesses have been discussed extensively in the literature (see Basha et al. 2008; Kussul et al. 2008; Matgen et al. 2011; Turner et al., 2016). Selecting a particular method for monitoring is therefore influenced by several factors such as the type of feature to be monitored, the accuracy required, availability of funding, type of output desired, the intended use of the results and geographical location (Dolan et al. 1991; Klemas 2015). 
Physical surveying generated historic maps detailed the mapped position of physical features influenced by flooding overtime as estimated on site by a land surveyor. Such maps provide accurate information for change detection as the surveyor is physically present during the data collection period (Graham et al. 2003; Leatherman et al. 2005). However, the approach tends to be limited both spatially and temporally due to several factors (Morton 1991; Smith and Jackson 1992). The method is time consuming, expensive and impractical for long distance mapping (Leatherman et al. 2005). It is also associated with human errors that can affect its reliability (Appeaning Addo et al. 2008). Aerial photographs are the most commonly used data source in coastal environment monitoring (Moore 2000). In addition to having the ability for stereo pair mapping, they also provide good spatial coverage (Lane et al. 2001). However, temporal coverage is very site specific and the process of acquiring the near vertical photographs as well as the laborious field preparation can be expensive (Whitehead et al. 2014; Darwin et al. 2013). This short coming affects the repeatability of the monitoring process.

Satellite imagery approach covers large area and provides detailed spectral information (Boak and Turner $2005)$ as well as very high resolution $(<1 \mathrm{~m})$ satellite data (Ford 2013).Satellites have short revisit time, provide multi-spectral data and have the capability for stereo pair mapping. However, they are affected by cloud coverage, dust during image acquisition, pixel resolution and operational cost (Whitehead et al. 2014; Darwin et al. 2013).

LIDAR has the ability to cover hundreds of kilometers of coastal area in a relatively short period and produce extremely dense and accurate elevation measurements (Stockdon et al. 2002). It is limited in its temporal and spatial availability because of cost (Boak and Turner 2005). Digital video imaging also has the capability to monitor detailed changes in the coastal systems (Boak and Turner 2005) and record flooding events in real-time. It also has the ability to collect both time-averaged and instantaneous images (Angnuureng et al. 2016). The sensor has a fixed location and a fixed area of coverage that makes it unsuitable for wider coverage monitoring.

Recent developments have resulted in the use of Unmanned Aerial Vehicles (UAVs) also known as drones in delta environment monitoring (Mancini et al. 2013; Klemas 2015). This is due to the relatively low cost of operation that allows for frequent missions, increased spatial coverage, no required installation points, rapid deployment, better quality outputs (Vousdoukas et al. 2011) and as a tool for effective communication. The ability of drones to perform missions and acquire data autonomously as well as its maneuverability capacity helps in complex coastal environmental disaster monitoring (Whitehead and Hugenholtz 2014; Wallace et al. 2012). Datasets produced by drone have high resolution $(<10 \mathrm{~cm})$ (Harwin and Lucieer 2012) and supports the development of high resolution digital elevation models (DEMs) that facilitate change detection and measurement (Hugenholtz et al. 2013). Drone based monitoring of disaster events has significant advantages due to its timeliness, event based rapid availability and better quality/resolution (Pérez-Alberti and Trenhaile 2015). Drones are also being used in advocacy to booster community awareness in various environmental hazards, including deforestation and bush fires and as a communication tool in stakeholder engagement at various levels (Goldberg et al. 2013; Mohammed et al. 2014). Appeaning Addo (2016) used drone video recordings to communicate erosion dynamics and flood problems to policy makers in Ghana (parliamentarian and local authorities), which influenced their perception about these problems (Owens 2016). The use of drone is therefore the best way in data gathering to arm decision makers and local authorities with more accurate picture of environmental impacts (STAFF AG 2017).

A major challenge to the operation of drone in the coastal environment of delta regions is the presence of strong winds (Gonçalves and Henriques 2015). Flights are therefore limited to specific times to reduce the impact of strong winds. Other challenges include platform instability, view angle, data processing tools and short flight times due to battery constraints (Elaksher et al. 2017). This paper presents the application of drones in flood monitoring in the Volta Delta in Ghana and sets up agenda for further studies in the Volta Delta. The drone technology was adopted for this study due to its advantages over the other methods, which will ensure repeated flood monitoring activity in the Volta Delta environment.

Flooding frequency and coastal erosion intensity as a result of intensive rainfall, oceanographic conditions (waves, sea level rise and tides) and human activities (watershed management) has increased in frequency and impact in the Volta Delta significantly. Construction of the Akosombo dam on the Volta River has been identified as a major cause of erosion and flooding problems in the Volta Delta region. Runoff before dam construction was higher $(87.5 \mathrm{~mm} / \mathrm{yr})$ and more varied than the post-dam period with value of $73.5 \mathrm{~mm} / \mathrm{yr}$. (Oguntunde et al. 2006). The dam construction (completed in 1965) has resulted in controlled water flow, which has changed the natural flooding of the area (Corcoran et al. 2007), although periodic high flooding from the tidal waves persist. The yearly sediment transport before the dam construction was about 7.5 million $\mathrm{m}^{3} / \mathrm{s}$ (Bollen et al. 2011). Since the 
construction of the dam, there are no peaks in flow discharge and the sediment transport is reduced to only a fraction of the original transport (Bollen et al. 2011). It is estimated that coastal erosion and flooding have destroyed about 5000 houses since the 1960s, displaced households, destroyed sources of livelihoods and forced migration within and out of the Delta (Boateng 2009; Karley 2009; Lumor 2015). Though riverine flooding occurs and particularly during the dam spillage, tidal flooding is dominant along the coastline of the Delta. The last reported Dam spillage was in November 2010 (Owusu and Waylen 2013) which cause flooding in communities along the river. However, tidal flooding in the Delta is on the increase as observed by previous reports (Bokpe 2010; Fagotto 2016).

\section{Application of drone in coastal zone monitoring}

Several studies have applied the drone technology in coastal environmental monitoring and achieved reliable results. The drone technic has been applied in tidal studies (Chabot and Bird 2014; Klemas 2015), wave run-up and coastal morphological change modelling studies (Casella et al. 2014) as well as bathymetric work (Delacourt et al. 2009). Harwin and Lucieer (2012) assessed the accuracy of drone by comparing the results with differential GPS and total station surveys. The study concluded that drone has high accuracy in coastal monitoring. Vousdoukas et al. (2011) compared the results of drone generated high quality time average images with images from satellite and video system, and concluded that drone has advantages over satellite and video system since it allows increased spatial coverage and a more favorable vantage point, as well as portability and rapid deployment.

Drone technique was used to acquire images of Aguda and Cabedelo in Portugal with ground resolution better than $5 \mathrm{~cm}$ and processed to achieve digital surface models with vertical accuracy ranging from $3.5 \mathrm{~cm}$ to $5 \mathrm{~cm}$ (Gonçalves and Henriques 2015). The accuracy achieved out matched the accuracies obtained from previous conventional aerial photography method (Gonçalves and Henriques 2015). According to Klemas (2015), digital elevation model (DEM) products from drones satisfy the resolutions mostly required for coastal environment applications. in another study, Mancini et al. (2013) compared data from drone point cloud, terrestrial laser scanner (TLS) and Global Navigation Satellite System (GNSS) survey and concluded that the results compare favourably (see also Chikhradze et al. 2015; Hackney and Clayton 2015). These studies have revealed drones extensive work flow and confirmed its accuracy as a tool for delta environment monitoring.

\section{Study area}

The Volta Delta is located in the eastern coast of Ghana within latitudes $5^{0} 25^{\prime}$ and $6^{0} 20^{\prime}$ North and longitude $0^{\circ} 40^{\prime}$ and $1^{0} 10^{\prime}$ East (Fig. 1). The delta is defined as the land below the $5 \mathrm{~m}$ contour in the lower portion of the Volta river basin within the Accra-Ho-Keta Plains (Appeaning Addo et al. 2018). Nine administrative districts that are responsible for managing resources in the Delta region are located wholly or partially in the Volta Delta. The delta is characterised by a fairly uniform, moderately steep shoreface with a gradient of between 1:120 and 1:150 down to $15 \mathrm{~m}$, which is considered as the close-out depth for significant wave-induced sediment movement on this coast (Rossi 1989; Anthony 2015). The wave climate in the region consists of swell waves from south-west direction (Angnuureng et al. 2013). The average significant wave height is about $1.4 \mathrm{~m}$ (Wellens-Mensah et al. 2002) while the annual maximum are around $2.5-$ $3 \mathrm{~m}$ (Roest 2018). Some variability in the wave climate is present over the year. The highest waves occur from July to August, while the lowest waves occur around January and February (Roest 2018). The tidal regime is semi-diurnal with a tidal range of about $1 \mathrm{~m}$ (Wellens-Mensah et al. 2002). The tidal currents are weak and their impact on the shoreline morphology is limited (Wellens-Mensah et al. 2002). Although the environment is microtidal, a study by Angnuureng et al. (2016) identified that short term evolution of the shoreline is affected by tidal cycles from neap to spring. Presently, the sea level is rising at a rate of about $3.1 \mathrm{~mm} / \mathrm{yr}$. (Sagoe-Addy and Appeaning Addo 2013). The sea level is predicted to continue rising in conformity to the global trend (Armah et al. 2005).

The basic winds along the study area are southwest monsoon. It blows from the south-west direction $\left(210^{\circ}-240^{\circ}\right)$ from the sea to land at about $45^{\circ}$ angle to the coast and it is approximately in the same direction with the waves (Angnuureng et al. 2013). During the Harmattan season (December-February) winds occasionally blow from the northwest. The monthly average wind speed ranges between 1.7 and $2.6 \mathrm{~m} / \mathrm{s}$ (Angnuureng et al. 2013).

Several studies have identified the Volta Delta as coastal erosion and flooding hotspot (Boateng 2012; Jayson-Quashigah et al. 2013; Appeaning Addo 2015). One community that suffered huge destruction of properties and displacement of households as a result of coastal flooding and erosion is Fuvemeh, a fishing community with over 1,500 inhabitants (see Fig. 1). The problems associated with the flooding incidents in the community require scientifically measured and reliable information to aid in effective management and developing a resilient community. 


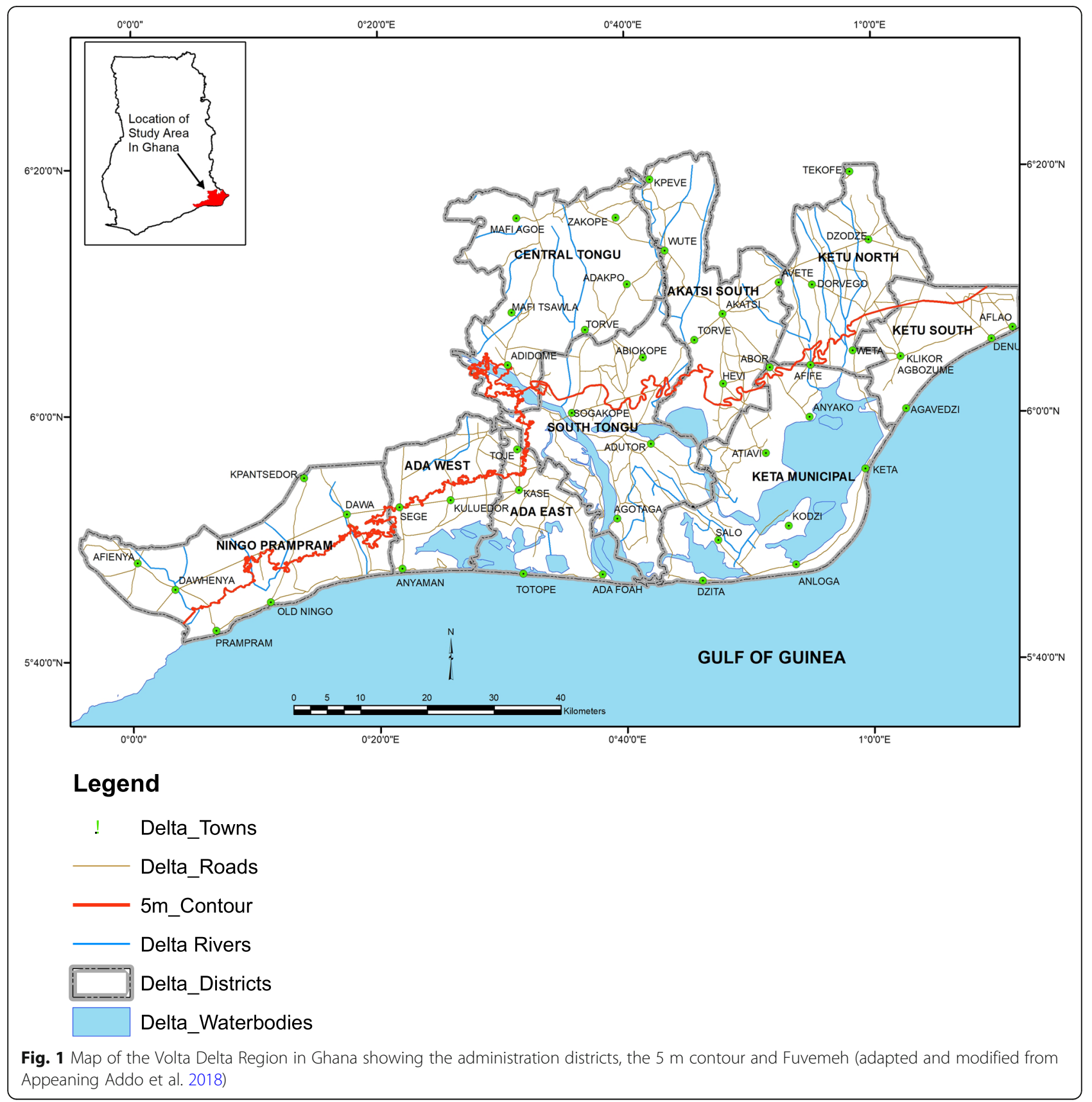

\section{Methods}

Rainfall data was obtained from Ghana Meteorological Agency (GMet) in Accra. Data on impact of flooding on people and buildings in the Keta environ within the Volta Delta region was obtained from the Ghana National Disaster Management Organisation (NADMO) in Keta. The data were used to analyse the rainfall trend in the region, frequency of human displacement and building collapsing as a result of flooding in the delta region. The rainfall data included recorded rainfall obtained from rain gauge station in Akatsi in the delta region from 1986 to 2015. The recorded number of people displaced and buildings collapsed by flooding were between the periods 2008 and 2014.

Orthophoto map of 2005 (0.5 m ground resolution) and satellite imagery of 2014 ( $1.0 \mathrm{~m}$ ground resolution) were obtained from the Survey and Mapping Division in Ghana and Digital Globe Foundation respectively for the Fuvemeh community. A DJI Phantom 3 drone was used to obtain aerial photographs ( $0.06 \mathrm{~m}$ ground resolution) of Fuvemeh community in February 2016 with repeated surveys in August 2016 and June 2017. Appeaning Addo 
et al. (2008) validated the 2005 orthophoto map and concluded that the map is accurate and reliable. The orthophoto map was therefore adopted as reference and used to validate the satellite imageries and the drone aerial photographs by checking the positional accuracies of selected features ( 5 buildings). The coordinates of the features on the satellite imageries and the drone pictures matched their conjugate coordinates on the orthophoto maps. This gave confidence in using the data for the study.

The shoreline positions, represented by the High Water Line (HWL) as proxy were mapped and appended in GIS environment to detect and measure change within the period under study. The Digital Shoreline Analysis System (DSAS) software developed by Thieler et al. (2017) was used to analyse the shoreline changing trends along equally spaced perpendicular transects along the coast. The transect intervals were set at $50 \mathrm{~m}$ to enable more areas to be covered in the rates of change estimation. The average rates of erosion were statistically estimated using the end point rate of change method (EPR). The EPR was adopted because it is the most commonly used method to compute shoreline rate of change (Genz et al. 2007). The method is simple and requires only two shoreline positions to obtain a rate of change. It calculates the rate of change by dividing the distance of shoreline movement by the time elapsed between the earliest and the latest measurement, which can be the oldest and the most recent shoreline positions (Crowell et al. 2005).

\section{Results}

Analysis of data obtained from NADMO revealed that several areas in the delta region are experiencing flooding problems. In all, 28 flooding events were recorded at varying intensity, which displaced over 2,000 people and destroyed about 306 buildings (Fig. 2).

It can be seen from Fig. 2 that between 2008 and 2014, several people were displaced by flooding event and significant number of houses were also destroyed. The highest number of displaced people (685) occurred in 2011, while the lowest number occurred in 2013. The highest number of houses (90) were destroyed in 2008 and the lowest number of houses (5) were lost in 2013. The high destruction of houses in 2008 can be attributed to storm surge which flooded the coastal zone in the delta region (Ghanaweb 2008) and flooding from rainfall. The severe flood experienced in 2011 was due to heavy rains that caused rivers to overflow their banks (Duodu 2011). Analysis of the rain gauge recorded data is presented in Fig. 3, which shows the annual rainfall distribution pattern and the general trend in Akatsi as per the linear trend line. It can be seen that between 1986 and 2015 the area recorded substantial amount of rainfall that resulted in flooding in some areas. The graph in Fig. 3 shows that 1986 to 1995 had mean rainfall value of $780.76 \mathrm{~mm}$, from 1996 to 2015 the rainfall value was $960.17 \mathrm{~mm}$ and then from 2006 to 2015 the mean rainfall average was $818.67 \mathrm{~mm}$. There was increasing trend from the first decade to the second decade of 1996 to 2005 and the trend decreased from the second decade of 1996 to 2005 and the third decade of 2006 to 2015. The general trend indicates increasing rainfall pattern in the delta region. Comparing Figs. 3 and 4 from 2008 and 2014, which falls within the 3rd decade, the decadal trend reduced similar to the significant reduced building destruction and displaced people, inferring reduced flooding events.

Analysis of the shoreline change using the 2005 orthophotos and 2017 drone images shows that the shoreline has moved inland several meters (about $100 \mathrm{~m}$ in some

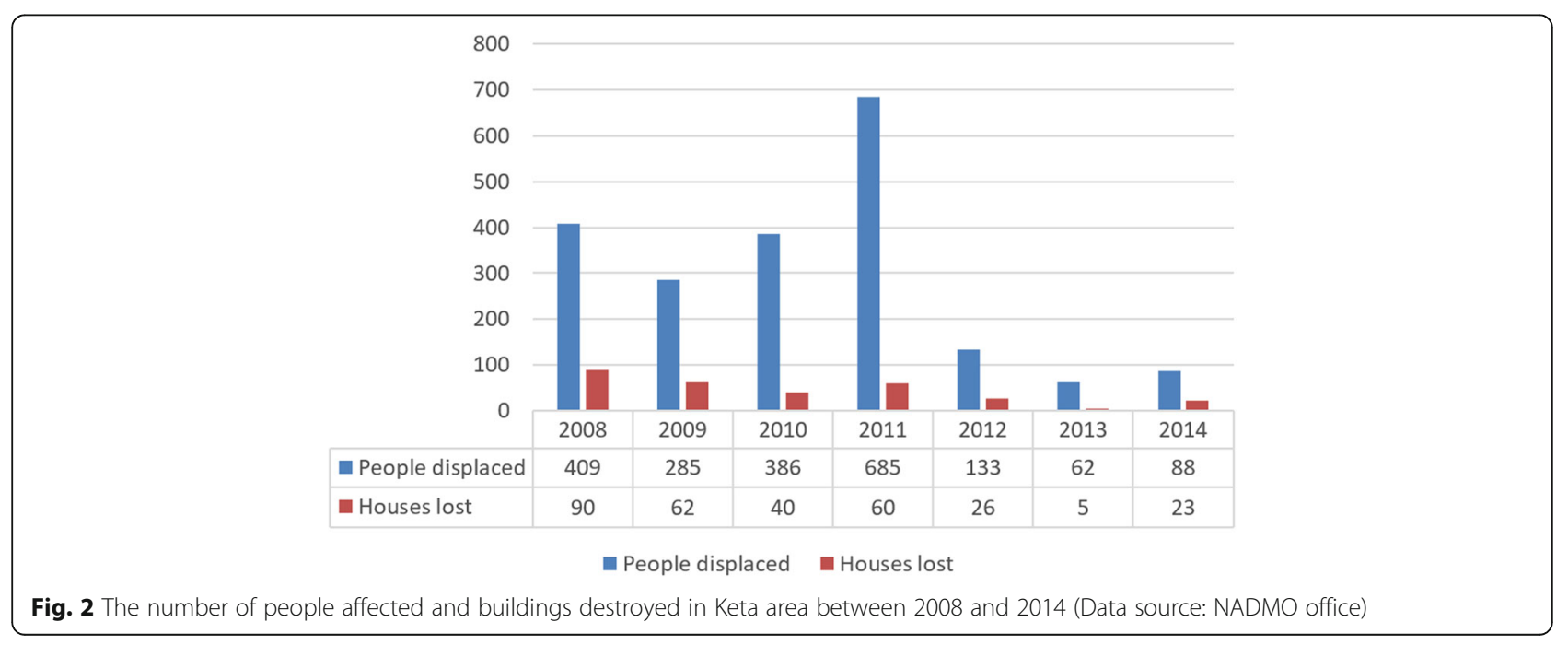


Akatsi Yearly rainfall graph

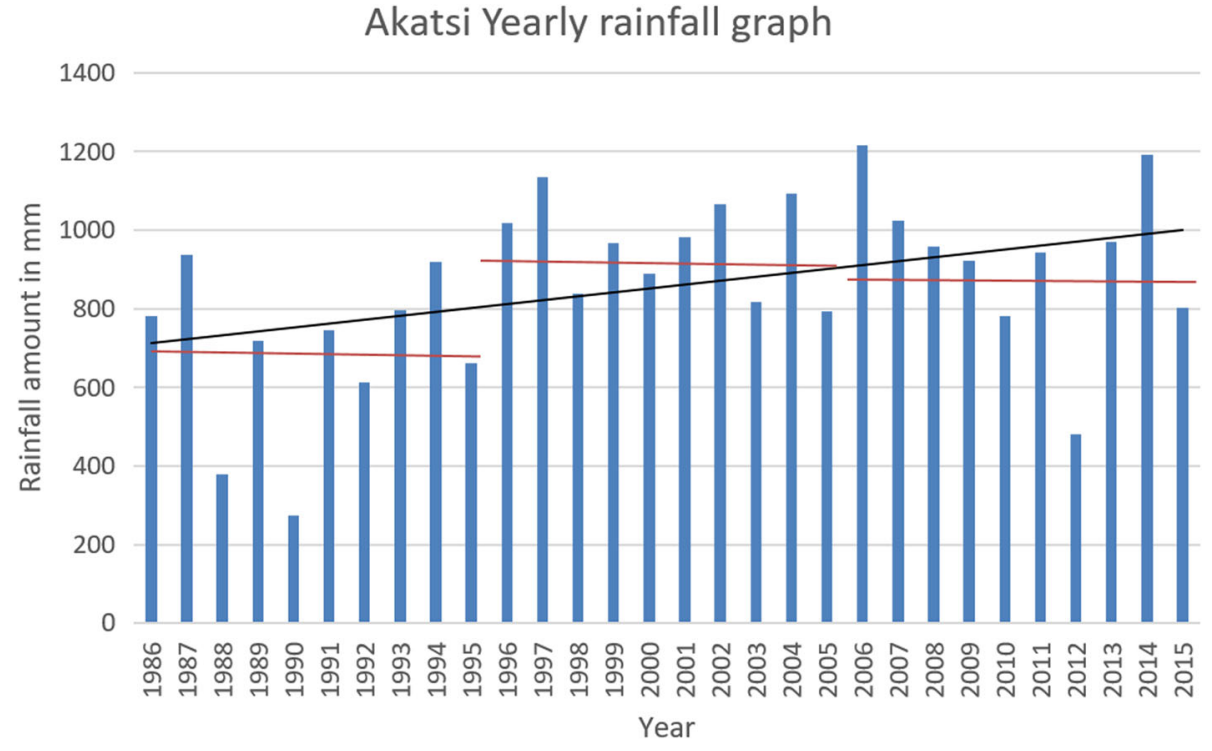

Fig. 3 Annual Rainfall (distribution) in Akatsi with the general and decadal trend lines (Data source GMet)

instances) along some perpendicular transects, while along some transects land has been gained (about $80 \mathrm{~m}$ in some instance) as can be seen in Fig. 4.

The shoreline migration trend analysis also revealed that out of a total area of about $375,229 \mathrm{~m}^{2}$, about $138,118.239 \mathrm{~m}^{2}$ of it has been lost as a result of erosion, which represent about $37 \%$ of the total land area. A total of about 77 houses have been destroyed by erosion between 2005 and 2017, which is about 42\% of the total houses in the Fuvemeh community. The destruction of the houses have resulted in the displacement of over 300 inhabitants in the Fuvemeh community. Figure 5 shows houses that have been lost between 2005 and 2017. Strong erosion as result of natural processes (e.g. sea level rise, storm surge, energetic swell waves, subsidence, etc.) and anthropogenic activities (dam construction, sand mining, over harvesting of mangroves, etc.) has damaged properties and destroyed the environment. It has also destroyed natural fish landing sites, which has affected the local fishing business (the main source of livelihood) and rendered some of the inhabitants' jobless (Boateng 2012).

Figure 6 shows part of the community in August 2013 from satellite imagery and the same area as captured by the drone in February 2016. The portion labelled A is the location of the only school in the community on both the August 2013 and February 2016 imageries. Comparing the two imageries in Fig. 6, it can be seen that the position of the school from the shoreline has changed. The portion labelled B on the satellite imagery shows part of the community in August 2013 which is now flooded on the February 2016 image. The lagoon on the August 2013 image is also lost on the February 2016 image.
Figure 7 shows the remains of the school building in May 2016 (A) and June 2016 (B) respectively.

Figure 8 shows drone image of the flooding event in the community captured on 9th February 2016. The energetic wave action, which were larger than the usual waves in the area, was aided by high tides and the prevailing relatively low topography, which is below $2 \mathrm{~m}$ above sea level (Boateng 2009) to break closer to the community and thus flood the Fuvemeh community. Figure 9 shows the devastating effect of the flood water on dwellings places (building labelled A) and sources of livelihood (labelled B).

The swash of the waves deposit debris onto the beaches, while the strong backwash carries properties of the inhabitants into the sea. The inhabitants have to salvage their properties and carry them to safe places (Fig. 10). Occupants of such flooded houses abandon the buildings and either stay with friends in safer areas or leave the community to other places as there is no government intervention. Some of the affected households remove the roofing sheets of their buildings to put up new buildings in less vulnerable areas.

\section{Discussions}

Analysis of the rainfall data revealed that the general pattern in the rainfall variability shows an increasing trend, which results in flooding and erosion. According to Allotey et al. (2008), the soil is often flooded during the wet season. Other factors that cause flooding along the coast in Fuvemeh and the Volta Delta include the occasional overflow of the Volta River when the spillways of Bagre and Akosombo dams are opened amid 


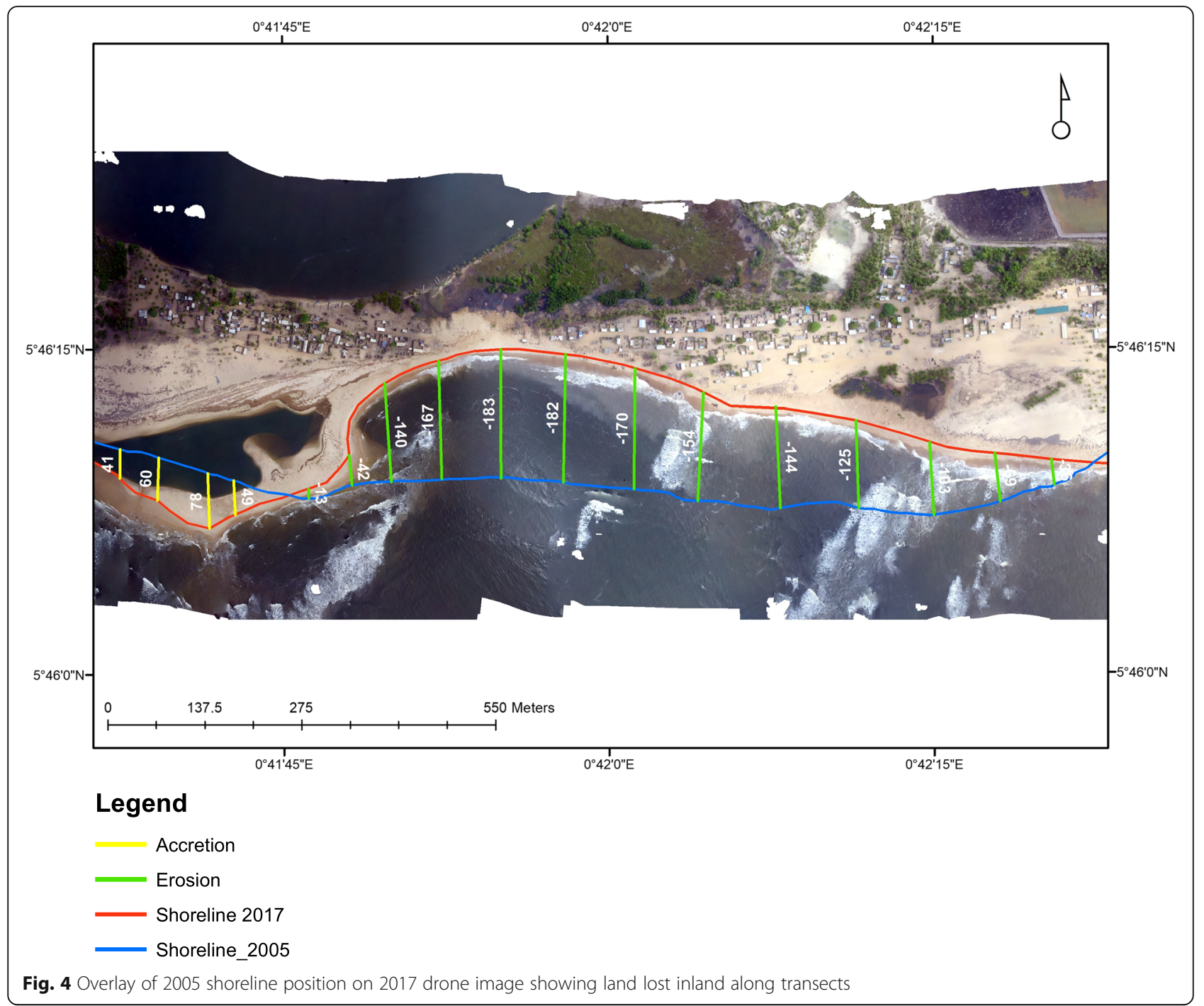

heavy rains (Biney 2010; Boateng 2012), strong energetic wave activities from the sea (Oteng-Ababio et al. 2011), occasional storm surge which has increased in frequency and intensity in recent times (Gakpo 2016), increasing relative sea level rise as a result of climate change, possible increased subsidence due to ground water extraction for irrigation and to a lesser extent tidal actions. Although the rate of subsidence has not been measured, it is expected to probably be between 1 and $2 \mathrm{~mm} / \mathrm{yr}$. based on other deltas (Syvitski 2008; Appeaning Addo et al. 2018). The rising sea level coupled with the relatively deep nearshore bathymetry (Jayson-Quashigah et al. 2013; Sagoe-Addy and Appeaning Addo 2013) enables the strong waves to break closer to the shoreline. Any sudden increase in wind intensity may result in a surge, which will further push the breaking waves more inland to flood the low lying areas. Over harvesting of mangroves for domestic use and converting mangrove vegetated areas to fish farms have reduced the natural protection they offer and thus rendered the environment vulnerable.

Analysis of the NADMO data shows the impact of flooding on the environment and the people. Flooding therefore has serious socioeconomic implication for the Fuvemeh community. The destruction of the school in the community will have huge implications on formal education delivery in the area. It emerged from informal discussions with members of the community that the destruction of the school building has increased the difficulty in assessing education facilities as the displaced school children now have to travel to nearby communities to attend school. The school building, according to some members of the community interviewed during the study, is used as a place of refuge during flood event in the community and the surrounding villages in the past. The collapse 


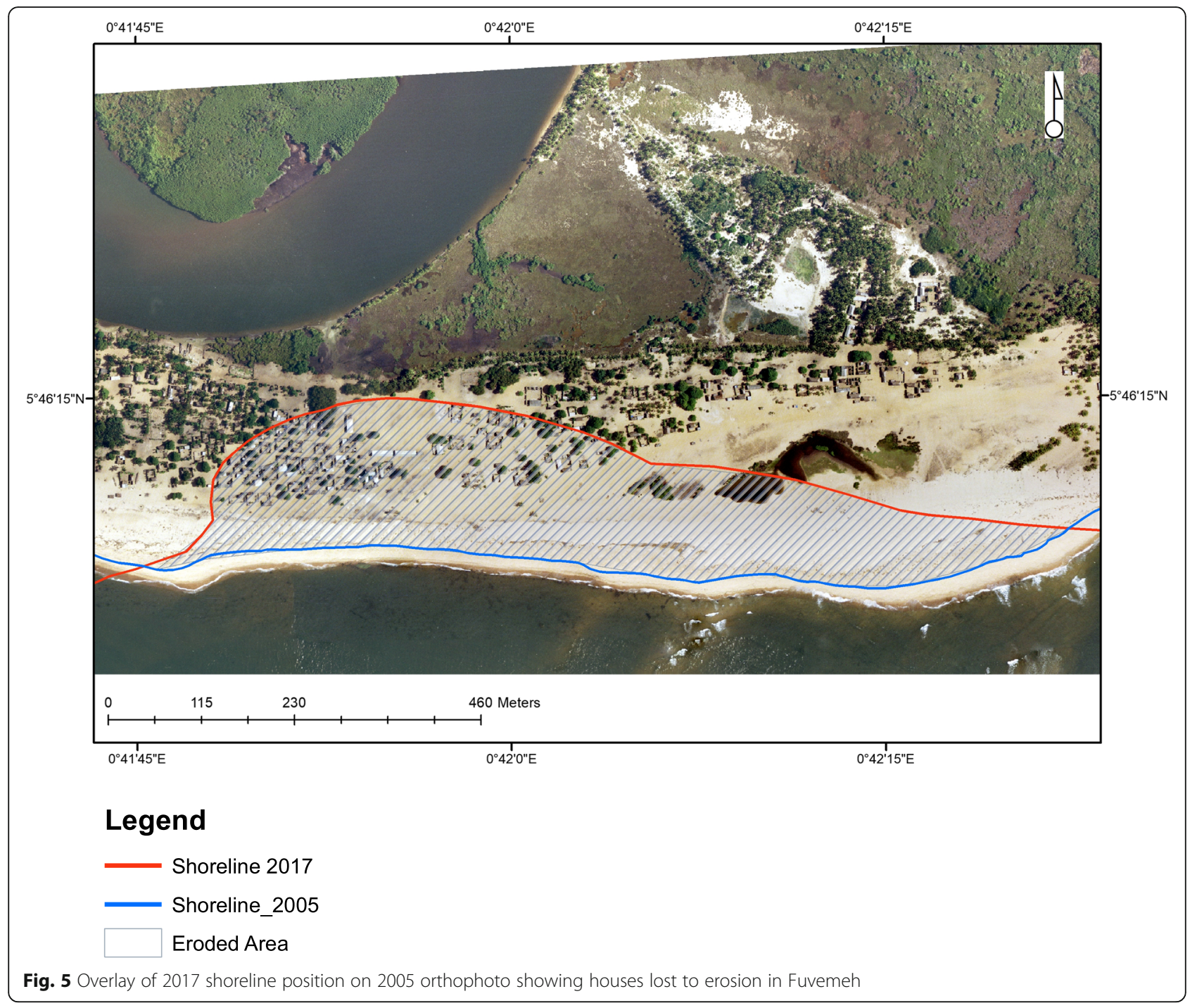

Fig. 5 Overlay of 2017 shoreline position on 2005 orthophoto showing houses lost to erosion in Fuvemeh

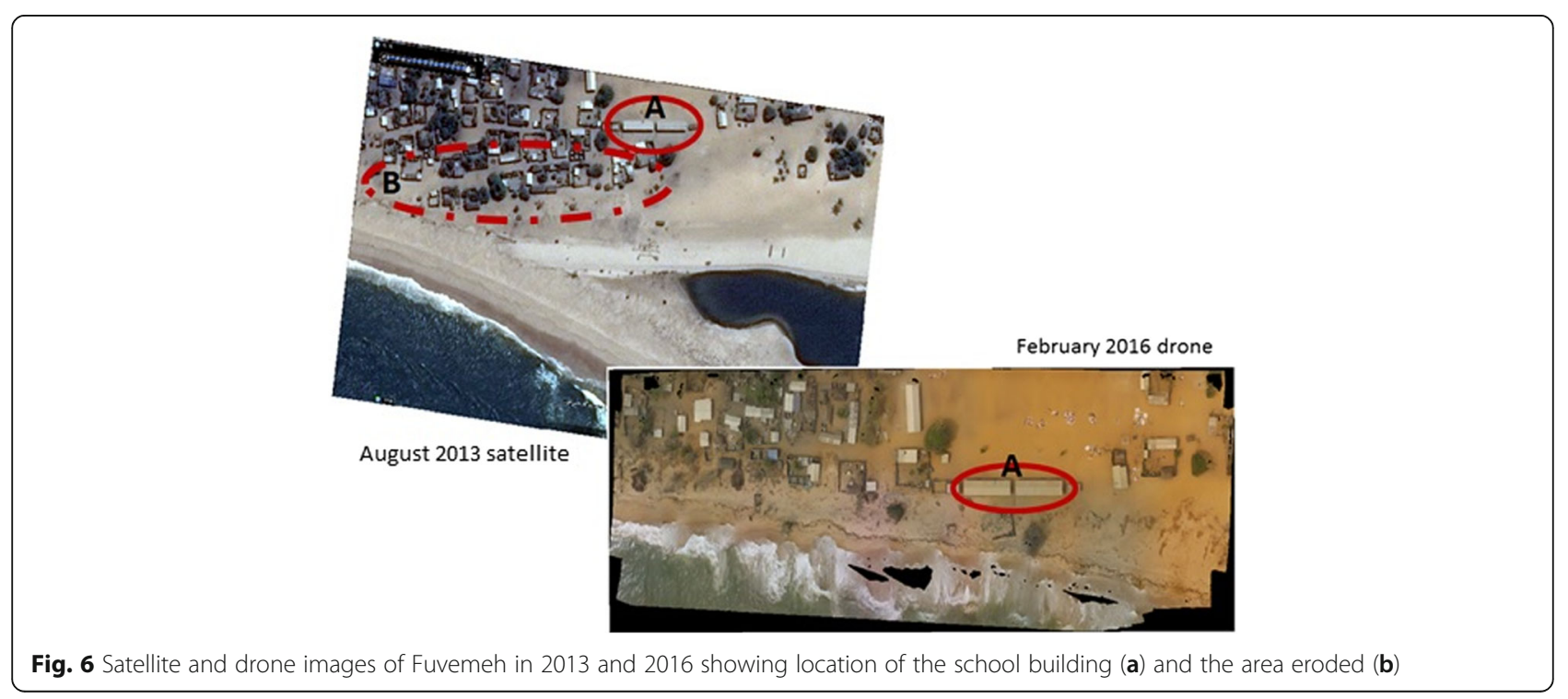



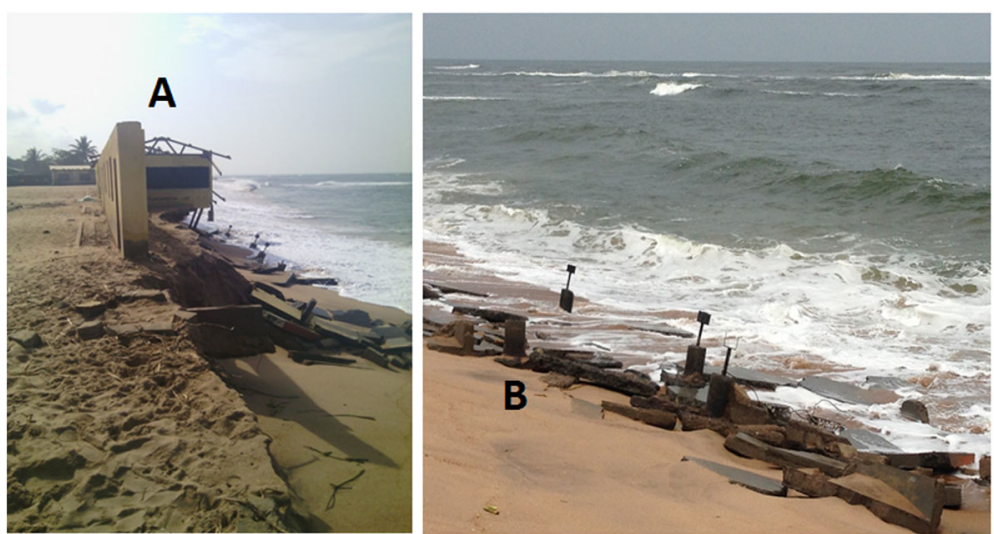

Fig. 7 State of the school building in May 2016 (a) and June 2016 (b)

of the school building will affect rescuing effort of NADMO during such disasters. The situation has also forced some of the inhabitants to migrate from the community to nearby communities, while others have moved from the delta region to other parts of the country and beyond (Mumuni et al. 2017). Destruction of natural fish landing sites by erosion has collapsed the small scale fishing industry and increased poverty in the community. This is expected to have a huge impact on the protein intake of the inhabitants in the community and the surrounding communities as well the food security in the country.

The changes in the shoreline migration trend being experienced in the study area are due to several factors such as energetic wave action, storm surge, dam constructed on the Volta River in Akosombo, the low topography of the beach system and sea level rise (Sagoe-Addy and Appeaning Addo 2013, Giardino et al. 2018). The construction of coastal defense structures in Ada (the up-drift side of Fuvemeh) and the reduced sediment discharge from the Volta River (Boateng 2012) has affected the sediment regime in the area. The defense structures are made up of groynes, which traps sediment and thereby starve the down-drift side of sediment as observed by Angnuureng et al. (2013) in Keta. The action of the groynes further enhances the impact of the reduced sediment discharge from the Volta River which has resulted in the observed morphological changes.

\section{Conclusions}

Coastal flooding and erosion are major issues in Fuvemeh and the entire Volta Delta. Their impact has intensified as a result of increased rainfall that results in rivers overflowing their banks; increased oceanographic conditions such as frequent storm surge activities, energetic swell waves, tidal activities and sea level rise that impact vulnerable communities like

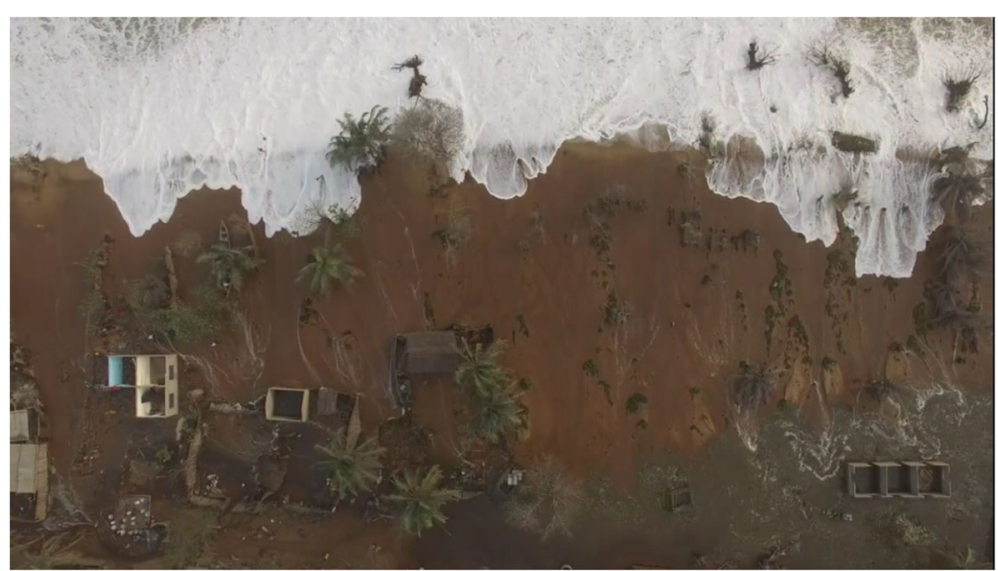

Fig. 8 Violent sea waves approaching the Fuvemeh community on 9th February 2016 


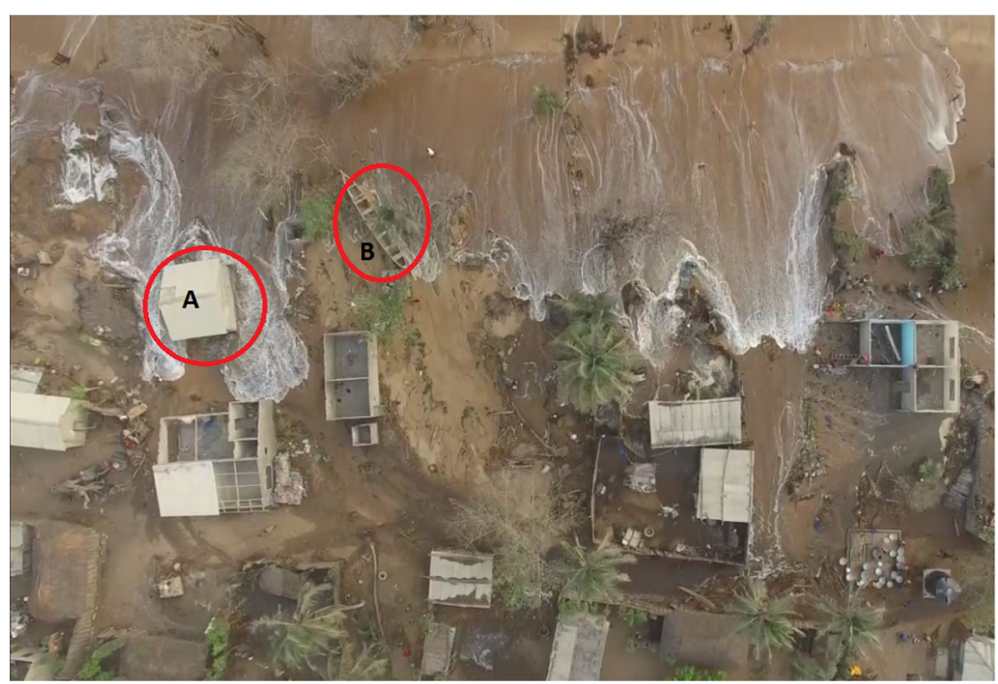

Fig. 9 Flooding in Fuvemeh affecting buildings (A) and fishing canoe (B)

Fuvemeh; upstream water catchment management such as construction of Akosombo dam on the Volta River which has influenced the sediment budget regime in delta system as well as the nearshore; overharvesting of mangroves that has destroyed the natural defence the vegetation provides and thereby opened the area to intense wave and tidal attacks; and sand mining for construction that has further affected the sediment budget regime. Coastal erosion and flooding in Fuvemeh have collapsed buildings (about $42 \%$ of the total houses); displaced inhabitants (about 300 inhabitants); destroyed sources of livelihood (about 37\% of Fuvemeh land, mainly natural fish landing sites along the coast, has been eroded and this has affected the local fishing business); and increased migration in the vulnerable areas (affected social and cultural dynamics in the Fuvemeh community). The problems will increase in future under changing climatic conditions. There is therefore the need to develop a sustainable adaptation approach to effectively manage the situation and increase the resilience of the inhabitants. Although the government has adopted building hard engineering structures to manage erosion and flooding, not all the areas experiencing such hazards can be managed using this approach. It is suggested that relocating the Fuvemeh community to a more secured place will be more appropriate and cost effective. Alternatively, a soft engineering approach such as beach nourishment can be adopted to augment the sediment shortage in the

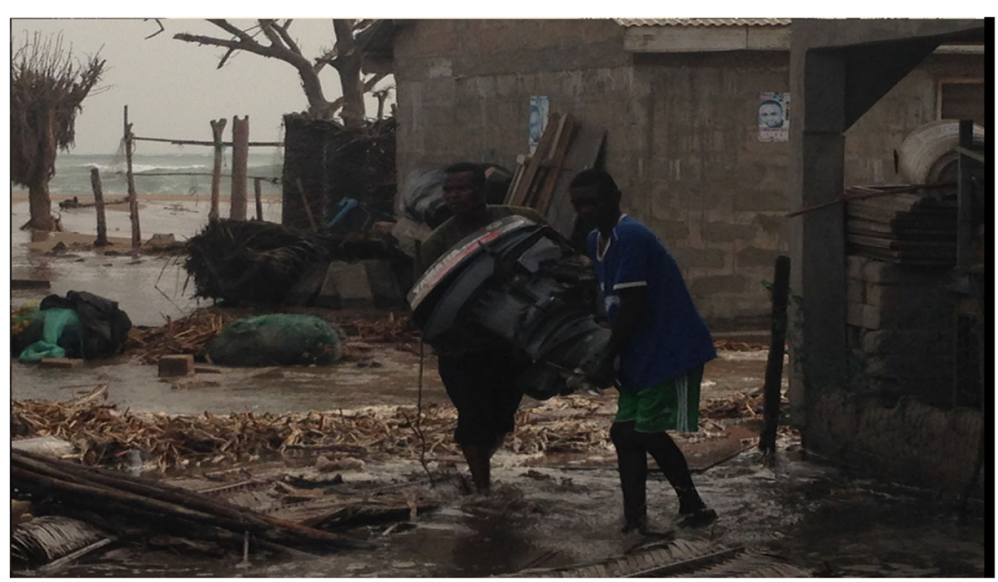

Fig. 10 Families carrying an outboard motor from a flooded house 
area. The study has further demonstrated the effectiveness of using the drone technology in monitoring flood and erosion in a delta community. The technology can therefore be applied in the fields of natural hazards, disaster response and high resolution terrain analysis.

\section{Abbreviations}

DEM: Digital Elevation Model; DSAS: Digital Shoreline Analysis System: EPR: End Point; GMet: Ghana Meteorological Agency; GNSS: Global Navigation Satellite System; GPS: Global Position System; HWL: High Water Line; LIDAR: Light Detection and Ranging; NADMO: Ghana National Disaster Management Organisation; RTK: Real-Time Kinematic; TLS: Terrestrial Laser Scanner; UAV: Unmanned Aerial Vehicles

\section{Acknowledgements}

This study was carried out under the Collaborative Adaptation Research Initiative in Africa and Asia (CARIAA), with financial support from the UK Government's Department for International Development (DFiD) and the International Development Research Centre (IDRC), Canada. The views expressed in this paper are those of the authors and do not necessarily represent those of DFiD and IDRC or its Board of Governors.

\section{Funding}

Funding for this work was provided by the International Development Research Centre (IDRC), Canada and the UK Government's Department for International Development (DFiD) as part of the Collaborative Adaptation Research Initiative in Africa and Asia (CARIAA).

\section{Availability of data and materials}

The data will be available at http://197.255.125.132/geonetwork

\section{Authors' contributions}

KAA; he designed the field work, supervised the work, developed the layout of the paper, contributed in writing the manuscript. PNJQ; he took part in the field data collection, analysed the rates of change, contributed to writing the manuscript. Samuel NAC; he contributed to writing the manuscript, reviewed the manuscript. FM; she analysed the rainfall data, contributed to writing the manuscript. All authors read and approved the final manuscript.

\section{Ethics approval and consent to participate} N/A

\section{Consent for publication}

All the co-authors consented for the publication.

\section{Competing interests}

The authors declare that they have no competing interests.

\section{Publisher's Note}

Springer Nature remains neutral with regard to jurisdictional claims in published maps and institutional affiliations.

\section{Author details}

'Department of Marine and Fisheries Sciences, College of Basic and Applied Sciences, University of Ghana, P. O. Box Lg 99, Legon, Accra, Ghana.

${ }^{2}$ Regional Institute for Population Studies, College of Humanities, University of Ghana, P. O. Box LG 96, Legon, Ghana. ${ }^{3}$ Ghana Meteorological Agency, P. O. Box Lg 87, Legon, Accra, Ghana.

Received: 9 May 2018 Accepted: 3 October 2018 Published online: 20 October 2018

\section{References}

Allotey, D.F.K., R.D. Asiamah, C.D. Dedzoe, and A.L. Nyamekye. 2008. Physicochemical properties of three salt-affected soils in the lower Volta Basin and management strategies for their sustainable utilization. West African journal of applied ecology 12(1):1-14.
Angnuureng, B.D., K. Appeaning Addo, and G. Wiafe. 2013. Impact of sea defense structures on downdrift coasts: The case of Keta in Ghana. Academia Journal of Environmental Science 1 (6): 104-121.

Angnuureng, D.B., R. Almar, K. Appeaning Addo, N. Senechal, B. Castelle, S.W. Laryea, and G. Wiafe. 2016. Video observation of waves and shoreline change on the microtidal Jamestown Beach in Ghana. In Proceedings of the 14th International Coastal Symposium (Sydney, Australia). Journal of Coastal Research, Special Issue, No. 75, pp. 1022-1026, ed. A. Vila-Concejo, E. Bruce, D. M. Kennedy, and R.J. McCarroll, 0749-0208. Coconut Creek (Florida): ISSN.

Appeaning Addo, K. 2015. Assessment of the Volta Delta shoreline change. Journal of Coastal Zone Management. 18: 408. https://doi.org/10.4172/jczm. 1000408.

Appeaning Addo K (2016) Drone footage of community flooding and coastal erosion in the Volta Delta. The DECCMA project. http://www.deccma.com/ deccma/projects_database/features/?action=story\&id=82 accessed 20/11/2017.

Appeaning Addo, K., R.J. Nicholls, S.N.A. Codjoe, and A. Mumuni. 2018. A biophysical and socio-economic review of the Volta Delta, Ghana. Journal of Coastal Research. https://doi.org/10.2112/JCOASTRES-D-17-00129.1.

Appeaning Addo, K., M. Walkden, and J.P. Mills. 2008. Detection, measurement and prediction of shoreline recession in Accra, Ghana. ISPRS Journal of Photogrammetry and Remote Sensing. 63 (5): 543-558.

Armah, A.K., G. Wiafe, and D.G. Kpelle. 2005. Sea-level rise and coastal. Biodiversity in West Africa: A case study from Ghana. In Climate change and Africa, ed. P. S. Low, 204-217. Cambridge: University press.

Basha, E.A., S. Ravela, and D. Rus. 2008. Model-based monitoring for early warning flood detection. In: Proceedings of the 6th ACM conference on embedded network sensor systems (pp. 295-308). Chicago: ACM.

Biney, C. 2010. Connectivities and linkages within the Volta Basin. The Global Dimensions of Change in River Basins 91.

Boak, E.H., and I.L. Turner. 2005. Shoreline definition and detection: A review. Journal of Coastal Research 21 (4): 688-703.

Boateng I (2009) Development of integrated shoreline management planning: A case study of Keta, Ghana. In: Proceedings of the Federation of International Surveyors Working Week 2009-surveyors key role in accelerated development, TS 4E, Eilat, Israel, 3-8 May.

Boateng, I. 2012. An assessment of the physical impacts of sea-level rise and coastal adaptation: A case study of the eastern coast of Ghana. Climatic Change 114 (2): 273-293.

Bokpe SJ (2010) HELP!...Azizanya is drowning. Retrieved march 1, 2018, From http://sethbnews09.blogspot.com/2010/08/helpazizanya-is-drowning-fridayaugust.html

Bollen, M., K. Trouw, F. Lerouge, V. Gruwez, A. Bolle, B. Hoffman, and P. Mercelis. 2011. Design of a Coastal Protection Scheme for Ada at the Volta-River mouth (Ghana). Coastal Engineering Proceedings 1 (32): 36.

Casella, E., A. Rovere, A. Pedroncini, L. Mucerino, M. Casella, L.A. Cusati, M. Vacchi, M. Ferrari, and M. Firpo. 2014. Study of wave run-up using numerical models and low-altitude aerial photogrammetry: A tool for coastal management. Estuarine, Coastal and Shelf Science 149: 160-167.

Chabot, D., and D.M. Bird. 2014. Small unamnned aircraft: Precise and convenient new tools for surveying wetlands. Journal of Unmanned Vehicle Systems 1: 15-24.

Chikhradze, N., R. Henriques, M. Elashvili, G. Kirkitadze, Z. Janelidze, N. Bolashvili, and G. Lominadze. 2015. Close range photogrammetry in the survey of the coastal area Geoecological conditions (on the example of Portugal). Earth 4 (5-1): $35-40$.

Corcoran, E., C. Ravilious, and M. Skuja. 2007. Mangroves of western and central Africa (No. 26). Chicago: UNEP/Earthprint.

Crowell, M., S.P. Leatherman, and B. Douglas. 2005. Erosion: Historical Analysis and Forecasting. In Encyclopedia of Coastal Science, Encyclopedia of Earth Sciences Series, ed. M.L. Schwartz, 428-432. the Netherlands: Springer.

Darwin, N., N.F.A. Hamid, W.S. Udin, and N.A.B. Mohd. 2013. Light weight rotarywing UAV for large scale mapping applications. Asia geospatial forum, 24-26. Kuala Lumpur, Malaysia: September.

Delacourt, C., P. Allemand, M. Jaud, P. Grandjean, A. Deschamps, J. Ammann, V. Cuq, and S. Suanez. 2009. DRELIO: An unmanned helicopter for imaging coastal areas, SI 56. In Proceedings of the 10th international coastal symposium, 1489-1493.

Dolan, R., M.S. Fenster, and S.J. Holme. 1991. Temporal Analysis of Shoreline Recession and Accretion. Journal of Coastal Research 7 (3): 723-744.

Duodu F (2011) Volta region submerged. General news, modern Ghana. https:// www.modernghana.com/news/342077/volta-region-submerged.html accessed 5/9/2018. 
Elaksher, A.F., S. Bhandari, C.A. Carreon-Limones, and R. Lauf. 2017. Potential of UAV lidar systems for geospatial mapping. In Lidar Remote Sensing for Environmental Monitoring 2017 (Vol. 10406, p. 104060L). International Society for Optics and Photonics.

Ericson, J.P., C.J. Vörösmarty, S.L. Dingman, L.G. Ward, and M. Meybeck. 2006. Effective Sea-level rise and deltas: Causes of change and human dimension implications. Global and Planetary Change 50 (1): 63-82.

Fagotto M (2016) West Africa Is Being Swallowed by the Sea: Encroaching waters off the coast of Togo, Ghana, Mauritania, and others are destroying homes, schools, fish, and a way of life. Retrieved March 1, 2018, from http:// foreignpolicy.com/2016/10/21/west-africa-is-being-swallowed-by-the-seaclimate-change-ghana-benin/

Ford, M. 2013. Shoreline changes interpreted from multi-temporal aerial photographs and high resolution satellite images: Wotje atoll, Marshall Islands. Remote Sensing of Environment 135: 130-140.

Gakpo JO (2016) Climate refugees: Life in Ghana's fast vanishing lands - 2. Joy news. | http://www.myjoyonline.com/opinion/2016/October-25th/climate-refugeeslife-in-ghanas-fast-vanishing-lands-2.php assessed on 6th November 2016.

Genz, A.S., C.H. Fletcher, R.A. Dunn, L.N. Frazer, J. John, and J.J. Rooney. 2007. The predictive accuracy of shoreline change rate methods and Alongshore Beach variation on Maui, Hawaii. Journal of Coastal Research 23 (1): 87-105.

Ghanaweb (2008) Relief for communities hit by tidal waves. https://www. ghanaweb.com/GhanaHomePage/NewsArchive/Relief-for-communities-hitby-tidal-waves-150323 Accessed 5/9/2018.

Giardino, A., R. Schrijvershof, C.M. Nederhoff, H. de Vroeg, C. Brière, P.K. Tonnon, and J. Schellekens. 2018. A quantitative assessment of human interventions and climate change on the west African sediment budget. Ocean \& Coastal Management 156: 249-265.

Goldberg D, Corcoran M, Picard RG (2013) Remotely piloted aircraft systems and journalism: Opportunities and challenges of drones in news gathering.

Gonçalves, J.A., and R. Henriques. 2015. UAV photogrammetry for topographic monitoring of coastal areas. ISPRS Journal of Photogrammetry and Remote Sensing 104: 101-111.

Graham, D.M., J.C. Sault, and J. Bailey. 2003. National Ocean Service Shoreline past, Present, and Future. Journal of Coastal Research SI (38): 14-32.

Hackney, C., and A. Clayton. 2015. Unmanned Aerial Vehicles (UAVs) and Their Application in Geomorphic Mapping. Geomorphological Techniques. In Bristish Society for Geomporlogy, ed. L. Lucy Clarke and J. Nield, 6.

Harwin, S., and A. Lucieer. 2012. Assessing the accuracy of georeferenced point clouds produced via multi-view stereopsis from unmanned aerial vehicle (UAV) imagery. Remote Sensing 4 (6): 1573-1599.

Hugenholtz, C.H., K. Whitehead, O.W. Brown, T.E. Barchyn, B.J. Moorman, A. LeClair, K. Riddell, and T. Hamilton. 2013. Geomorphological mapping with a small unmanned aircraft system (sUAS): Feature detection and accuracy assessment of a photogrammetrically-derived digital terrain model. Geomorphology 194: 16-24.

Jayson-Quashigah, P.-N., K. Appeaning Addo, and K.S. Kodzo. 2013. Medium resolution satellite imagery as a tool for monitoring shoreline change. Case study of the eastern coast of Ghana. Journal of Coastal Research 65: 551-516.

Karley, N.K. 2009. Flooding and physical planning in urban areas in West Africa: Situational analysis of Accra, Ghana. Theoretical and Empirical Researches in Urban Management 13: 25.

Klemas, V.V. 2015. Coastal and environmental remote sensing from unmanned aerial vehicles: An overview. Journal of Coastal Research 31 (5): 1260-1267.

Kussul, N., A., Shelestov, S., Skakun, and O. Kravchenko. 2008. Data assimilation technique for flood monitoring and prediction. International Journal "Information Theories \& Applications" 15(2008):76-83.

Lane, S.N., J.H. Chandler, and K. Porfiri. 2001. Monitoring river channel and flume surfaces with digital photogrammetry. Journal of Hydraulic Engineering 127 (10): 871-877.

Leatherman, S.P., D. Whitman, and K. Zhang. 2005. Airborne Laser Terrain Mapping and Light Detection and Ranging. In Encyclopedia of Coastal Science. Encyclopedia of Earth Sciences Series, ed. M.L. Schwartz, 21-23. the Netherlands: Springer.

Lumor, M. 2015. Estimation of Streamflow and Fluvial Sediment Loads in the White Volta Basin under Future Climate Change. In 2015 AGU Fall Meeting Agu.Catalyst (2015). Catalyst quick take: Women in male-dominated industries and occupations in U.S. and Canada, 2015. New York: Catalyst.

Mancini, F, M. Dubbini, M. Gattelli, F, Stecchi, S, Fabbri, and G Gabbianelli. 2013. Using unmanned aerial vehicles (UAV) for high-resolution reconstruction of topography: The structure from motion approach on coastal environments. Remote Sensing 5 (12): 6880-6898.

Matgen, P., R. Hostache, G. Schumann, L. Pfister, L. Hoffmann, and H.H.G. Savenije. 2011. Towards an automated SAR-based flood monitoring system: Lessons learned from two case studies. Physics and Chemistry of the Earth, Parts A/B/C 36 (7): 241-252.

Mohammed, F., A. Idries, N. Mohamed, J. Al-Jaroodi, and I. Jawhar. 2014. UAVs for smart cities: Opportunities and challenges. In Unmanned Aircraft Systems (ICUAS), 2014 International Conference IEEE, 267-273.

Moore, L.J. 2000. Shoreline mapping techniques. Journal of Coastal Research 16 (1): 111-124

Morton, R.A. 1991. Accurate shoreline mapping: Past, present and future. In Coastal sediment'91, edited by Kraus, 997-1010. New York: N. C.

Mumuni, A., Y. Atiglo, C. Addoquaye-Tagoe, and S. Codjoe. 2017. Descriptive statistics from sending area survey data - Volta Delta. Royal Senchi, Ghana: Ghana. DECCMA consortium workshop.

Oguntunde, P., J. Friesen, N. van de Giesen, and H.H.G. Savenije. 2006. Hydroclimatology of the Volta River basin in West Africa: Trends and variability from 1901 to 2002. Physics and Chemistry of the Earth 31: 1180-1188.

Oteng-Ababio, M., K. Owusu, and K. Appeaning Addo. 2011. The vulnerable state of the Ghana coast: The case of Faana-Bortianor. Jàmbá: Journal of Disaster Risk Studies 3 (2): 429-442.

Owens B (2016) Drones on the Delta: In Ghana's Volta River Delta, the remotely-operated aerial vehicles are going where researchers can't to help study coastal erosion, flooding and migration.http://idrc. canadiangeographic.ca/education/docs/ghana-drones-delta-workbook.pdf (Accessed 10/08/2017).

Owüsu, K., and P. Waylen. 2013. The changing rainy season climatology of midGhana. Theoretical and Applied Climatology. 112 (3): 419-430. https://doi.org/ 10.1007/s00704-012-0736-5.

Pérez-Alberti, A., and A.S. Trenhaile. 2015. An initial evaluation of drone-based monitoring of boulder beaches in Galicia, north-western Spain. Earth Surface Processes and Landforms 40 (1): 105-111 Pix4D, (2013). Pix4D Mapper Pro: http://pix4d.com/pix4dmapper-pro/.

Roest LWM (2018) The coastal system of the Volta Delta, Ghana: Strategies and opportunities for development. TU Delft Delta Infrastructures and Mobility Initiative (DIMI).

Rossi, G. 1989. L'e'rosion du littoral dans le Golfe du Be 'nin: un exemple de perturbation d'un e'quilibre morphodynamique. Zeitschrift fu' $r$ Geomorphologie NF Suppl Band 73: 139-165.

Sagoe-Addy, K., and K. Appeaning Addo. 2013. Effect of predicted sea level rise on tourism facilities along Ghana's Accra coast. Journal of Coastal Conservation and Management. 17 (1): 155-166. https://doi.org/10.1007/ s11852-012-0227-y.

Smith, A.W.S., and L.A. Jackson. 1992. The variability in width of the Visible Beach. Shore and Beach 60 (2): 7-14.

STAFF AG (2017) Wilderness society to use drones to raise awareness of deforestation. Australian geographic. http://www.australiangeographic.com. au/news/2017/01/wilderness-society-to-use-drones-to-raise-awareness-ofdeforestation (Accessed 15/01/2018).

Stockdon, H.F., A.H. Sallenger, H.J. List, and R.A. Holman. 2002. Estimation of shoreline position and change using airborne topographic lidar data. Journal of Coastal Research 18 (3): 502-513.

Syvitski, J.P. 2008. Deltas at risk. Sustainability science 3 (1): 23-32 Journal of sustainable development; 9(3); 2016. ISSN 1913-9063 E-ISSN 1913-907.

Thieler ER, Himmelstoss EA, Zichichi JL, Ergul A (2017) Digital Shoreline Analysis System (DSAS) version 4.0-An ArcGIS extension for calculating shoreline change (ver. 4.4, July 2017): U.S. Geological Survey Open-File Report 2008 1278, https://pubs.er.usgs.gov/publication/ofr20081278 (Accessed 12/12/2017).

Turner, I.L., M.D. Harley, and C.D. Drummond. 2016. UAVs for coastal surveying. Coastal Engineering Volume 114: 19-24.

Vousdoukas, M.I., G. Pennucci, R.A. Holman, and D.C. Conley. 2011. A semiautomatic technique for Rapid Environmental Assessment in the coastal zone using Small Unmanned Aerial Vehicles (SUAV). Journal of Coastal Research SI 64: 1755-1759 (Proceedings of the 11th International Coastal Symposium), Szczecin, Poland.

Wallace, L., A. Lucieer, C. Watson, and D. Turner. 2012. Development of a UAV-LiDAR system with application to Forest inventory. Remote Sensing 4: 1519-1543.

Wellens-Mensah, J., A.K. Armah, D.S. Amlalo, and K. Tetteh. 2002. Ghana National Report Phase 1: Integrated problem analysis. GEF MSP sub-Saharan Africa 
project (GF/6010-0016): Development and protection of the coastal and marine environment in sub-Saharan Africa. Accra.

Whitehead, K., and C.H. Hugenholtz. 2014. Remote sensing of the environment with small unmannned aircraft systems (UASs), part 1: A review of progress and challenges. Journal of unmanned Vehicle Systems 2: 69-85.

Whitehead, K., C.H. Hugenholtz, S. Myshak, O. Brown, A. LeClair, A. Tamminga, T.E. Barchyn, B. Moorman, and B. Eaton. 2014. Remote sensing of the environment with small unmanned aircraft systems (UASs), part 2: Scientific and commercial applications1. Journal of Unmanned Vehicle Systems 02 (03): 86-102.

Wong, P.P., I.J. Losada, J.P. Gattuso, J. Hinkel, A. Khattabi, McInnes KL, Y. Saito, and A. Sallenger. 2014. Coastal systems and low-lying areas. In Climate Change 2014: Impacts, Adaptation, and Vulnerability. Part A: Global and Sectoral Aspects. Contribution of Working Group II to the Fifth Assessment Report of the Intergovernmental Panel on Climate Change, ed. C.B. Field, V.R. Barros, D.J. Dokken, KJ. Mach, M.D. Mastrandrea, T.E. Bilir, M. Chatterjee, K.L. Ebi, Y.O. Estrada, R.C. Genova, B. Girma, E.S. Kissel, A.N. Levy, S. MacCracken, P. R. Mastrandrea, and L.L. White, 361-409. Cambridge and New York, NY: Cambridge University Press.

\section{Submit your manuscript to a SpringerOpen ${ }^{\circ}$ journal and benefit from:}

- Convenient online submission

- Rigorous peer review

- Open access: articles freely available online

- High visibility within the field

- Retaining the copyright to your article

Submit your next manuscript at $\boldsymbol{\nabla}$ springeropen.com 